Krzysztof WOJCIECHOWSKI

KUL Lublin

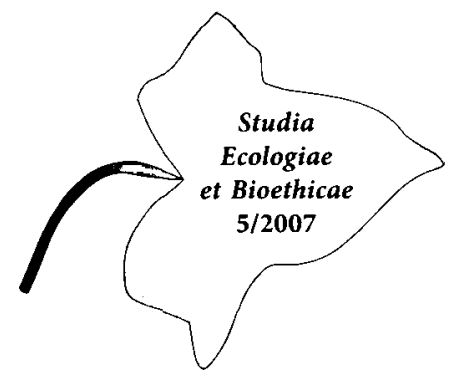

\title{
Potrzeba edukacji bioregionalnej
}

Bezpośrednią przyczyną napisania tej pracy było z pozoru błahe wydarzenie. Razu pewnego wybrałem się z moimi siostrzeńcami na stary, prawosławny, ukraiński cmentarz, jaki położony jest w mojej rodzinnej wsi (przed wojną w większości zamieszkałej przez Rusinów-Ukraińców) na Zamojszczyźnie. Niezrozumiałe ruskie napisy na nagrobkach wzbudziły ciekawość kilkuletnich dzieci. Zacząłem więc wyjaśniać im, gdzie jesteśmy. Na co najstarszy mój siostrzeniec ze zdziwieniem zapytal: „To po co Ukraińcy robili u nas cmentarze, a nie u siebie". Pytanie było tym bardziej zaskakujące, że jak się okazuje wielce prawdopodobnym jest, iż spoczywa na tym cmentarzu któryś z jego przodków. Skłoniło mnie to do refleksji nad sensem i brakami współczesnej edukacji oraz do przedstawienia propozycji jej uzupełnienia. Uzupełnienia o coś co nazywane jest edukacją bioregionalną. Podkreślić należy, iż w pracy nie używam tego terminu w jego pierwotnym znaczeniu, a ze względu na polską specyfikę nieco go zmodyfikowałem mając nadzieję, że nie zatracam głównego przesłania.

Bioregion w ujęciu klasycznym (kanadyjskiego poety Allena Van Newkirk 1974) to połączenie życia (bio) i obszaru (region) używane dla określenia filozofii i sposobu patrzenia na przestrzenne organizmy biologiczno-kulturowe ${ }^{1}$. To określony naturalnymi granicami (rzadziej sztucznymi) obszar odróżniający się szeregiem cech od obszarów otaczających. Nie jest to li tylko jednostka fizycznogeograficzna, bowiem przyroda jest tylko jedną ze składowych bioregionu. Drugą ważną składową są znajdujące się na terenie bioregionu wytwory ludzkie.

Bioregionem mogą być obszary stosunkowo duże powierzchniowo (np. Polesie, Roztocze, Śląsk czy Podlasie), ale bioregionem może być również jedna gmina czy nawet wioska. Od innych bioregionów różni się on szeregiem cech. Są to cechy związane tak z przyrodą (ukształtowanie terenu, pokrycie roślinnością, klimat czy charakterystyczne gatunki dominujące tutaj), jak i innymi sferami: odmienna historia, a co za tym idzie odmienna język, gwara, typ budownictwa, ubiór, struktura społeczna ludności, religia itd.

1 J Korbel, M. LeLeK, W obronie ziemi - radykalna edukacja ekologiczna, Pracownia na rzecz Wszystkich Istot, 1995. 
Bioregionalizm zaś jest nurtem odwołującym się zarówno do bogactwa kultur związanych $z$ danym miejscem $i$ wyrosłych $z$ lokalnych uwarunkowań jak też i do biologicznej różnorodności miejsca. Van Newkirk proponuje jako podstawowe narzędzia dla studiów bioregionalnych takie dziedziny, jak: ekologia, historia kultury, studia nad miejscowym językiem, lokalna mitologia, poezja. Ja dołączę do tego historię w ogóle, etnografię oraz historię „religii i wyznan””, badania socjologiczne itp. oraz zespół cech absolutnie nie mierzalnych i nie mieszczących się chyba w granicach żadnych nauk i badań. Są to cechy związane z odczuwaniem miejsca, osobistą wrażliwością człowieka, poczuciem swojskości - zupełnie subiektywne ${ }^{2}$.

Edukacja bioregionalna jest zatem nauczaniem o bioregionie w możliwie najszerszym zakresie tematycznym. Edukacja bioregionalna, jak i bioregionalizm zaczyna się od zadania sobie pytania: gdzie jestem? Jaki kształt terenu określa region? Jaka jest flora, fauna, wody, gleby? Jakie są najbardziej charakterystyczne formy budownictwa, które można by nazwać tradycyjnymi, jakie materiały były w użyciu?3. Ale także: jaka jest historia tego terenu? Kto zamieszkiwał go przede mną i kto zamieszkuje teraz? Jakie narodowości? Jaki wyznania i religie? Co i gdzie po tych czasach zostało? itp. Kluczowe jest tutaj łączenie obu sfer funkcjonowania człowieka: natury i kultury czy też cywilizacji.

\section{Po co edukować bioregionalnie?}

Edukacja bioregionalna nie ma być alternatywą dla edukacji ekologicznej czy regionalnej. Powinna być ich logicznym i twórczym połączeniem oraz w wielu przypadkach uzupełnieniem. Potrzeba prowadzenia tego typu edukacji wydaje się być bezoporna. Powodów jest kilka:

Przede wszystkim edukuje się po to, by wiedzieć. By poznać własne otoczenie zwiększyć wiedzę i świadomość o tym terenie, poznać jego historię, przyrodę, chlubne i czarne karty. Poznać historie ludzi, którzy tutaj żyli, przy okazji być może również dzieje własnej rodziny.

Poznanie powinno prowadzić do wzmocnienia więzi z własnym otoczeniem, z miejscem, w którym się człowiek urodził i wychował. Po to aby móc spłacić dług tej ziemi i tym ludziom, którzy wpływali na kształtowanie się człowieka, na jego wzrastanie fizyczne i duchowe. $Z$ tego stanowiska bardzo latwo przejść do patriotycznej roli edukacji bioregionalnej. Jedynie czując wieź ze swym najbliższym otoczeniem, pracując i działając dla niego można mówić o patriotyzmie również

Por. K. Wojciechowski, Bioregionalizm praktyczny, Dzikie Życie, marzec 2003, nr 3(105).

3 J. Korbel, M. LeleK, $W$ obronie ziemi - radykalna edukacja ekologiczna, Pracownia na rzecz Wszystkich Istot, 1995. 
w szerszym ujęciu - miłości ojczyzny. W Biblii jest takie porównanie, iż nie można kochać Boga, którego się nie widzi a nie kochać bliźniego, którego się widzi. Parafrazując te słowa można napisać: jak można być patriotą, kochać Polskę, Ojczyznę, Najjaśniejszą Rzeczypospolitą, jeśli nie szanuje się własnej wioski czy gminy i nie interesuje się zupełnie jej losem?. Miłość ojczyzny winna zaczynać się od rzeczy drobnych czyli od miłości własnego „haimatu”. W przeciwnym przypadku mówienie o patriotyzmie jest tylko pustosłowiem i populizmem.

Wiedza i uczucie powinny się przekładać na działanie. Stare łacińskie przysłowie mówi, iż historia jest nauczycielka życia. Poznanie historii własnego terenu, jej skutków powinno prowadzić do unikania w przyszłości zła, jakie było kiedyś. Ale nie tylko, poznanie stanu obecnego oraz potrzeb powinno stymulować do działania na rzecz wspólnoty, ziemi, własnego bioregionu. Owocem edukacji winny być też działania ochronne zmierzające do zachowania tak wartości przyrodniczych tego obszaru - które zawsze są podstawą bytu mieszkańców, jak i do jego walorów kulturowych, cywilizacyjnych.

Jednym z istotnych celów edukacji bioregionalnej jest to, by jeszcze mocniej podkreślić silne związki regionalizmu i przyrody (często niestety nie akcentowane ani przez regionalistów z jednej strony, ani przez np. członków przyrodniczych organizacji pozarządowych $z$ drugiej), by uświadomić, że jedno ma na drugie często bardzo ścisły wpływ. Aby w przyszłości jedno drugiemu nie było przeciwstawiane. Jak pokazują liczne przykłady z kraju wielokrotnie stawia się po dwóch przeciwnych stronach dobro ludzi, zachowanie walorów czy obiektów kulturowych i ochronę środowiska. Tymczasem w rzeczywistości takiego rozdźwięku praktycznie nie ma.

I na koniec edukacja bioregionalna winna stanowić uzupełnienie do tradycyjnych form edukacji. Powinna zapełnić pewną lukę, jaka wg mnie, istnieje w obecnej edukacji szkolnej, a przejawiającej się tym, że dziś dzieci wiedzą jak wygląda żyrafa, a nie wiedzą jak wygląda mazurek czy rudzik, ani też kto, kiedy i z jakiego powodu postawił krzyż na końcu wsi. Stwierdzenia te, zda się banalne, pokazują efekt i sposób kształcenia, które powinno być nieco zmienione.

\section{Jak edukować?}

Edukacja bioregionalna jest zadaniem bardzo trudnym. Wynika to głownie $z$ jej zakresu. Obejmuje ona bowiem szereg dziedzin nieraz zupełnie ze sobą nie związanych, wymaga zatem olbrzymiej wiedzy merytorycznej i bardzo dobrego przygotowania dydaktycznego i metodycznego. Można powiedzieć, że edukację bioregionalną mogą prowadzić tylko pasjonaci - ludzie autentycznie zakochani w jakimś bioregionie, niekoniecznie swoim. Prócz wiedzy, osoba prowadząca tego typu edukację powinna odznaczać się również wieloma innymi cechami: 
szerokim spojrzeniem, wrażliwością, brakiem uprzedzeń i tolerancją. Wiedza, zwłaszcza historyczna, o bioregionie jest bowiem nieraz bardzo zawiła i skomplikowana. Rzutuje na nią wiele przyczyn politycznych, społecznych i innych. I człowiek bez szerokiego spojrzenia i bez poczucia odnalezienia i przekazania prawdy w takiej edukacji się nie sprawdza. Ale co więcej, nie wystarczy jedynie prawda, konieczna jest jeszcze wrażliwość po to, aby ta przekazywana prawda nie antagonizowała a uczyła.

Dlatego ze względu na zakres i trudności w edukacji bioregionalnej proponuję dwa sposoby jej prowadzenia. Metoda liderska czy też pozytywistyczna, polegającą na tym, aby jedna osoba nauczyciela, regionalisty, pozarządowca czy innego społecznika prowadziła sama zajęcia ustawicznie się doszkalając i uzupełniając swoją wiedzę. Bądź też metoda kolektywna. Ta $z$ kolei polega jedynie na koordynowaniu przez lidera, którym może być lokalny nauczyciel, regionalista, duchowny i inny zaangażowany człowiek, zajęć bioregionalnych, zapraszaniu ciekawych osób posiadających wiedzę na temat bioregionu, moderowaniu dyskusji czy spotkań. Zadanie to jest nie mniej odpowiedzialne, jednak w pewnym stopniu zwalnia prowadzącego $\mathrm{z}$ ustawicznego uzupełniania wiedzy. Można powiedzieć, iż lider w metodzie kolektywnej powinien bardziej posługiwać się "czuciem i wiarą" niż „szkiełkiem i okiem”.

Sam sposób prowadzenia zajęć powinien być jak najbardziej zróżnicowany i urozmaicony. W jak najmniejszym stopniu powinien odbywać się w salach. Jest to przestrzeń zamknięta, izolująca od bioregionu. Nawet treści historyczne łatwiej będą przyswajane przy pomniku czy grobie partyzantów lub powistańców, niż w sali lekcyjnej. Zajęcia przyrodnicze powinny być prowadzone $w$ terenie $\mathrm{z}$ czynnym zaangażowaniem edukowanych. O powstaniu parafii najlepiej mówić przy kościele czy na cmentarzu, o starych czasach - gawędząc $z$ dziadkiem i babcią na ławeczce w sadku czy ogródku. Prócz walorów edukacyjnych tego typu zajęcia mają niewątpliwe zalety zdrowotne oraz uwrażliwiające. Nauczany stale przebywa „w bioregionie", nie ogląda ścian w sali, a drzewa, budynki czy krajobrazy swojej małej ojczyzny.

Aby edukacja bioregionalna przyniosła wymierne skutki powinna być ona powszechna. Dotychczas namiastki edukacji bioregionalnej można było zaobserwować w tzw. ścieżkach międzyprzedmiotowych, jednak to zdecydowanie za mało. Podejmują edukację bioregionalną różne osoby lub NGO-sy w całym kraju, jednak jest to ciągle edukacja nieformalna. Jej słabą stroną jest przede wszystkim brak funduszy na działania, brak dobrych metodycznych wskazówek i podręczników $w^{4}$ i wreszcie brak odpowiednich ludzi. Gros przykładów takich działań

4 Przykładem ciekawych opracowań mogących służyć jako podręczniki do lokalnej edukacji bioregionalnej są wydane wspólnie przez IOP PAN, IB PAN i ISF publikacje z serii „Mówić o Bogu..., a zwłaszcza: A. Dyduch-FalniowsKa, M. GrzegorCzyK, Z.J. KiJAS, Z. MireK,(red.), 
jest jak najbardziej pozytywnych, wynikających i prowadzonych z potrzeby serca i z autentycznej miłości do własnego bioregionu, znajdą się jednak i takie, które prowadzone są byle jak i stanowią jedynie pretekst do pozyskania środków na działania konkretnej organizacji. Takie działania (których na szczęście jest niewiele) nie tylko nie przynoszą efektów, a jeśli prowadzą je osoby nieprzygotowane i nieodpowiedzialne - mierzalne szkody.

Często też to "rynek" źródeł finansowania kształtuje kierunki tej edukacji. Innymi słowy organizacje, stowarzyszenia i osoby prywatne piszą granty „pod konkretne projekty" nie zaś zgodnie $\mathrm{z}$ aktualnymi potrzebami swego bioregionu. To również może odbijać się negatywnie na efektach edukacji.

\section{Przykłady edukacji bioregionalnej w Polsce}

Edukacja bioregionalna jest $w$ Polsce realizowana $w$ przez szereg podmiotów: szkół, NGO-sów, osób indywidualnych, choć często nazywa się ją nieraz inaczej (np. edukacją regionalną, ekologiczną itp.). Poniżej prezentuję kilka wybranych przykładów:

- Wspólnota ekologiczna BIOS z Chełma, prowadzona przez małżeństwo nauczycieli (Dariusza i Liliannę Kosteckich, on polonista, ona biolog). Funkcjonuje już od 1992 roku. Młodzież pod kierunkiem nauczycieli opracowuje ścieżki edukacyjne i historyczne, bierze udział w zajęciach przyrodniczych w terenie itp. Ideę, sposób i cel działania Wspólnoty dobrze ilustruje poniższy cytat $\mathrm{z}$ jednego $\mathrm{z}$ jej wydawnictw: „Wiemy, dobrze wiemy, że byleś $z$ rodzicami $w$ Berlinie, że Rzym odwiedziłeś w czasie wakacji, a na narty jeździsz do Słowacji, a w przyszłym roku na obóz językowy wybierzesz się do Londynu. Nie o tym jednak chcemy $z$ Toba dzisiaj rozmawiać. Czy widziałeś kiedyś powietrzne, godowe tańce blotniaków? Czy styszałeś klangor żurawia albo przedziwny śpiew bąka, który udaje, że dmucha w pusta butelkę? Zaprowadzimy Cię do zabytkowego pałacu i parku w Serebryszczu, opowiemy Ci o petnych tajemnic ruinach dworku w Stawie, a potem kto wie, może sam zaczniesz szukać miejsc bliskich i niezwyklych"s.

- Klub Młodego Ekologa przy Szkole Podstawowej w Chruślinie prowadzony przez panią Barbarę Kreto. Dzieci pod jej kierunkiem prowadzą konkursy na najładniejszy ogród, opracowują zeszyciki edukacyjne nt. zdrowej żyw-

Mówić o Stwórcy i przyrodzie. Przewodnik edukacyjny, Instytut Ochrony Przyrody PAN, Instytut Studiów Franciszkańskich, Kraków 2000 oraz: M. Grzegorczyk, J. Perzanowska (red.), Skarby przyrody i kultury Krakowa i okolic, Instytut Ochrony Przyrody PAN, Ośrodek Studiów Franciszkańskich WT PAT, Instytut Nauk o Środowisku UJ, Wydawnictwo WAM, Kraków 2005.

5 L. Kostecka, D. Kostecki (red.), Wspólnota ekologiczna BIOS 1992-2002, Chełm 2002. 
ności, ginących zawodów, oraz ścieżkę rowerową doliną rzeki, nad którą leży Chruślina ${ }^{6}$. W jednym $\mathrm{z}$ zeszycików autorka pisze: „Każdy $z$ nas ma swoja małą Ojczyznę. Tę w której się wychowat, która go ksztattowała. (...) Zupetnie inaczej jest odbierana z zewnątrz, lecz dla społeczności, która tam żyje i poznaje ja od środka jest $w$ rzeczywistości wielkim cieplym domem"7. Edukacja ta przynosi wymierne efekty w postaci tego choćby, że znaczy procent uczniów z Chruśliny wybiera jako kierunek studiów ochronę środowiska.

- Szerokie działania edukacyjne prowadzone w oparciu o projektowany Międzynarodowy Rezerwat Biosfery „Polesie Zachodnie” realizowały: Stowarzyszenie Poleskie i Ekologiczny Klub UNESCO - Pracownia na rzecz Bioróżnorodności z Piask. Wieloletnim zasłużonym prezesem tych organizacji (aż do swojej tragicznej śmierci) był Janusz Kuśmierczyk. Działania obejmowały m.in. wydawnictwa "Zaczarowane Polesie", konferencje naukowe i spotkania warsztatowe na terenie Polesie, spotkania międzynarodowe z uczestnikami z Ukrainy, Białorusi, Portugali, Niemiec, Rumunii i Włoch, warsztaty pozyskiwania funduszy itd ${ }^{8}$.

- Na terenie Beskidu Śląskiego i Żywieckiego działania bioregionalne prowadzi Jacek Zachara ze Stowarzyszeniem „Olszówka”, m.in. wydajać serię ciekawych zeszytów pod wspólnym tytułem „Edukacja bioregionalna”"

- Edukację bioregionalną w ujęciu chrześcijańskim, w ramach prowadzonych od 12 lat warsztatów ekologicznych REFA prowadzi Ruch Ekologiczny św. Franciszka z Asyżu ${ }^{10}$.

- Od trzech lat funkcjonuje na Lubelszczyźnie projekt „Kształtujemy tożsamość krajobrazu" prowadzony przez dr Jadwigę Michalczyk z KUL JP II wraz $\mathrm{z}$ Kuratorium Oświaty w Lublinie. W ramach projektu nazywanego lubelskim eksperymentem krajobrazowym uczniowie pod nadzorem nauczycieli i architektów krajobrazu zakładają ogrody przyszkolne. Poza tym organizowane są konkursy i konferencje edukacyjne (dotychczas trzy, kolejna planowana w 2007 r.) a także wydawane materiały pokonferencyjne ${ }^{11}$.

6 B. Kreto, J. Kreto, Doliną rzeki Podlipie ścieżka rowerowa, Lublin (bez daty wydania)

7 B. KRETO, Śladami zawodów ginących, Intrograf, Lublin 2002.

8 Zakres działalności Janusza Kuśmierczyka i wspomnianych organizacji był zbyt szeroki, by go tutaj opisywać, zainteresowanych odsyłam do opracowań bardziej szczegółowych: K. WoJcIECHOWsKI, Edukacja dla ekorozwoju. Działalność Ekologicznego Klubu UNESCO. Pracownia na Rzecz Bioróżnorodności i Stowarzyszenia Poleskiego na polu edukacji ekologicznej na Polesiu i terenach nadbużańskich. W: Edukacja ekologiczna jako element integracji wokól lokalnych problemów ochrony środowiska. (Materiały konferencyjne). Puławy 2002; WojcIEchowski K., 2004, Wspótpraca organizacji pozarzadowych $w$ ramach Rezerwatu Biosfery "Polesie Zachodnie" i europejskiego korytarza ekologicznego doliny Bugu, w: A. HA£ADYJ (red.), Wspótpraca międzynarodowa w ochronie środowiska, Wyższa Szkoła Handlowa w Radomiu, Radom, s. 151 - 161

9 J. ZaChara, Rozejrzyj się wokół swojego domu, Stowarzyszenie Olszówka, Bielsko-Biała 2001.

10 Więcej na ten temat można przeczytać na stronie internetowej Ruchu: www.refa.franciszkanie.pl

1 J. Michalczyk (red.), Kształtujemy tożsamość krajobrazu, Kuratorium Oświaty w Lublinie, Lublin 2004; J. MichalCzYK (red.), Człowiek a krajobraz, Kuratorium Oświaty w Lublinie, 
- Działania bioregionalne prowadzi również na Lubelszczyźnie Stowarzyszenie Ekologiczno-Społeczne „Zielona Swoboda” z Michowa. Polegaja one na aktywnej ochronie przyrody Pradoliny Wieprza i powiatu lubartowskiego oraz na zachowywania dla przyszłych pokoleń miejscowych podań, folkloru ${ }^{12}$ i edukowaniu dzieci.

Wszystkie te inicjatywy (których jest w skali naszego kraju znacznie więcej) zasługują na wsparcie i docenienie. Jednak aby nie były one jedynie działaniami doraźnymi, edukacja bioregionalna powinna być powszechna.

\section{Literatura}

Chоміuк M., Dziwy spod strzechy $i$ wierzbowej dziupli, Lubartów (bez daty wydania).

Dyduch-Falniowska A., Grzegorczyk M., Kijas Z. J., Mirek Z.,(red.), 2000, Mówić o Stwórcy i przyrodzie. Przewodnik edukacyjny, Instytut Ochrony Przyrody PAN, Instytut Studiów Franciszkańskich, Kraków.

Grzegorczyk M., Perzanowska J. (red.), 2005, Skarby przyrody i kultury Krakowa $i$ okolic, Instytut Ochrony Przyrody PAN, Ośrodek Studiów Franciszkańskich WT PAT, Instytut Nauk o Srodowisku UJ, Wydawnictwo WAM, Kraków.

Korbel J., LELEK M.,1995,W obronie ziemi - radykalna edukacja ekologiczna, Pracownia na rzecz Wszystkich Istot.

Kostecka L., Kostecki D. (red.), 2002, Wspólnota ekologiczna BIOS 1992-2002, Chełm.

KRETo B., 2002, Śladami zawodów ginacych, Intrograf, Lublin.

Kreto B., KReto J., Dolina rzeki Podlipie ściezka rowerowa, Lublin (bez daty wydania).

Michalczyк J.(red.), 2004, Kształtujemy tożsamość krajobrazu, Kuratorium Oświaty w Lublinie, Lublin.

Michalczy J.(red.),2005, Człowiek a krajobraz, Kuratorium Oświaty w Lublinie, Lublin.

MICHALCZYK J.(red.),2006, Czlowiek a środowisko, KUL JP II, Kuratorium Oświaty w Lublinie.

WojcIEchowski K., 2002, Edukacja dla ekorozwoju. Działalność Ekologicznego Klubu UNESCO Pracownia na Rzecz Bioróżnorodności i Stowarzyszenia Poleskiego na polu edukacji ekologicznej na Polesiu i terenach nadbużańskich. W: Edukacja ekologiczna jako element integracji wokół lokalnych problemów ochrony środowiska. (Materiały konferencyjne). Puławy.

WoJciechowski K., 2003, Bioregionalizm praktyczny, Dzikie Życie, marzec, nr 3(105)

WOJCIECHOWsкi K., 2004, Wspólpraca organizacji pozarzadowych w ramach Rezerwatu Biosfery „Polesie Zachodnie” i europejskiego korytarza ekologicznego doliny Bugu, w: Haładyj A. (red.), Współpraca międzynarodowa w ochronie środowiska, Wyższa Szkoła Handlowa w Radomiu, Radom, s. 151 - 161.

ZACHARA J., 2001, Rozejrzyj się wokół swojego domu, Stowarzyszenie Olszówka, Bielsko-Biała.

Lublin 2005; J. MichalCzYK (red.), Czlowiek a środowisko, KUL JP II, Kuratorium Oświaty w Lublinie, Lublin 2006.

12 M. Cноміuк, Dziwy spod strzechy i wierzbowej dziupli, Lubartów (bez daty wydania). 